\title{
Internal doses of French adult population linked to the intake of radionuclides from the decay-chains of uranium and thorium by foodstuffs ingestion
}

\author{
Ph. Renaud ${ }^{\star}$, V. Parache and S. Roussel-Debet \\ IRSN, BP3, 13108 Saint-Paul-Lez-Durance, France.
}

Received 15 July 2014 - Accepted 20 November 2014

\begin{abstract}
This study provides the first dose assessment to the French adult population due to the intake of radionuclides from the decay chains of uranium and thorium by foodstuff ingestion (water consumption excepted). This dose varies widely with the consumption of seafood, from less than $200 \mu \mathrm{Sv} \cdot \mathrm{y}^{-1}$ for people who do not consume shellfish or crustaceans at all, to more than 2,000 $\mu \mathrm{Sv}^{-1} \mathrm{y}^{-1}$ for the biggest consumers (about $150 \mathrm{~kg} \cdot \mathrm{y}^{-1}$ according to specific dietary surveys carried out along the French seaside). For moderate consumers of seafood (around $4.6 \mathrm{~kg} . \mathrm{y}^{-1}$ ), who probably represent a major part of the population, this internal dose would be around $330 \mu \mathrm{Sv}_{\mathrm{y}} \mathrm{y}^{-1}$. This variable consumption of seafood overshadows all the other causes of variability of these internal dose estimates.
\end{abstract}

Keywords: ingestion doses / radionuclides of uranium and thorium decay-chains

\section{Introduction}

Potassium 40 and the radionuclides of the ${ }^{238} \mathrm{U}$ and ${ }^{232} \mathrm{Th}$ decay chains are the main contributors to the internal dose due to the intake of natural radionuclides by the ingestion of foodstuffs. The potassium content being strictly regulated by the organism and the amount of ${ }^{40} \mathrm{~K}$ being well known and stable, the dose due to this nuclide is thus around $170 \mu \mathrm{Sv}_{\mathrm{y}} \mathrm{y}^{-1}$ for an adult (UNSCEAR, 2000). However, many studies show that the dose due to the intake of U-Th chain nuclides depends on the foodstuff activities, and above all on dietary habits, notably the consumption of seafood (Rollo et al., 1992; Yamamoto et al., 1994; Pietrzack-Flis et al., 1997a, 1997b, 2001; Desideri et al., 2011). Due to their high dose conversion factors and their high activities in foodstuffs, ${ }^{210} \mathrm{Po},{ }^{210} \mathrm{~Pb},{ }^{228} \mathrm{Ra}$ and ${ }^{226} \mathrm{Ra}$ could contribute more than $98 \%$ to this dose (UNSCEAR, 2000).

The study carried out by Picat et al. (2002) showed that the French data were at this time insufficient to have a good idea of the activity levels of natural radionuclides in French foodstuffs, particularly as regards these four nuclides. For this reason, no more accurate dose assessments such as those performed by UNSCEAR on the global scale could be made for France. Since the mid-90s, ${ }^{210} \mathrm{~Pb},{ }^{228} \mathrm{Ac}$ and ${ }^{214} \mathrm{Bi}$ (decay products of ${ }^{228} \mathrm{Ra}$ and ${ }^{226} \mathrm{Ra}$, respectively) are quite regularly provided in the results of gamma spectrometry performed by the Institute for Radioprotection and Nuclear Safety (IRSN) for its missions of radiological monitoring in the environment and

\footnotetext{
^ philippe.renaud@irsn.fr
}

research studies. Moreover, due to the high amount of ${ }^{210} \mathrm{Po}$ in seafood, some ${ }^{210} \mathrm{Po}$ analyses have been carried out since 2002 on mussels, oysters and fishes from the Channel and the Mediterranean coast. On this basis, reference values have been established by Renaud et al. (2015a, 2015b) concerning the activity of these four nuclides in French foodstuffs.

The aim of this study is to estimate the internal doses to the French population using these reference values and the consumption rates established from French dietary surveys.

\section{Material and method}

Table 1 presents the reference values obtained by Renaud et al. (2015a, 2015b) for the different categories of foodstuffs proposed by UNSCEAR, to which 3 supplementary foodstuffs have been added (small fishes, crustaceans and shellfish). In France, the mean value of ${ }^{238} \mathrm{U}$ activity in soil is equal to ${ }^{232} \mathrm{Th}$ one (around $40 \mathrm{~Bq} \cdot \mathrm{kg}^{-1}$ dry), and most French soils present activities between 20 (in limestone regions) and $50 \mathrm{~Bq} \cdot \mathrm{kg}^{-1}$ dry (on granitic or metamorphic rocks). Therefore, previous studies show that it is not possible to distinguish activities of samples from regions with a gap of only a factor of 2 between their soil activities due to the strong variability of transfer to plants and animal products. This is in agreement with Blanco Rodriguez et al. (2002), having shown that the linearity of the relation between soil activities and plant activities in real agricultural conditions (unlike experimental conditions) is effective for a concentration range of at least 2 orders of magnitude. Furthermore, temporal records measured for the same crop on 
Table 1. Reference values of ${ }^{226} \mathrm{Ra},{ }^{228} \mathrm{Ra},{ }^{210} \mathrm{Po}$ and ${ }^{210} \mathrm{~Pb}$ activities (mBq. $\mathrm{kg}^{-1}$ fresh matter) from Renaud et al. (2015a, 2015b).

\begin{tabular}{lcccc}
\hline & ${ }^{\mathbf{2 2}} \mathbf{R a}$ & ${ }^{\mathbf{2 1 0}} \mathbf{P b}$ & ${ }^{\mathbf{2 1 0}} \mathbf{P o}$ & ${ }^{\mathbf{2 2}} \mathbf{R a}$ \\
\hline Milk products & 11 & 27 & 30 & 10 \\
Meats & 50 & 100 & 100 & 43 \\
Cereals & 180 & 410 & 410 & 180 \\
Leafy-vegetables & 90 & 340 & 340 & 90 \\
Root-vegetables and fruits & 51 & 120 & 120 & 57 \\
Fishes & 160 & 550 & 2000 & 160 \\
Crustaceans and shellfish & 400 & 550 & 22500 & 130 \\
Large fishes/cephalop. & 160 & 550 & 2000 & 160 \\
Small fishes & 160 & 550 & 10000 & 160 \\
Crustaceans & 400 & 550 & 18000 & 130 \\
Shellfish & 400 & 1000 & 27000 & 130 \\
\hline
\end{tabular}

the same site show that variability at the local level is as significant as the variability between Districts with various U-Th contents in soils. It follows that the average activity of a kind of foodstuff established from the data acquired over the whole territory is representative enough to assess the average intake to a person consuming this kind of food throughout the year, even if this product comes exclusively from a specific place.

Concerning the isotopes of uranium and thorium, the reference values proposed by UNSCEAR are still used for dose assessments, knowing that they potentially contribute less than $2 \%$ to the total ingestion dose (UNSCEAR, 2000).

The French dietary habits on the scale of the whole territory are known through 3 national surveys (Bertrand, 1993; Volatier, 2000; Lafay, 2009). The quantities consumed provided in the reports are not directly usable for dose assessment as they are not given for the food categories of Table 1. Most often, it is necessary to sum the rations: lettuce, spinach and cabbage for the leafy vegetable category; and pork, veal, beef and mutton for the meat category. When quantities are those of transformed products or cooked meals, it is necessary to estimate the contribution of the various categories. For example, a sandwich can be considered as composed of $50 \%$ cereals and $50 \%$ meat, thus neglecting possible components such as vegetables or butter. In the same way, pastries can be seen as a mix of $70 \%$ cereals, $20 \%$ milk (butter) and $10 \%$ neglected others. For the survey reported by Bertrand (1993) this work was done by Mourlon (2012). The same methodology was applied for the two other surveys. In addition to these national surveys, six local surveys were performed in order to find out local dietary habits around some nuclear facilities: Tricastin, Chinon, Marcoule, Gravelines, Blayais and Nord-Cotentin (La Hague) (Dufour and Volatier, 1998; Parache, 2009, 2010, 2011, 2012). These studies specifically acquired for internal dose assessments are much better suited to this study and require only minor adaptations.

Table 2 presents the mean values of the quantity consumed for each foodstuff categories on the basis of the results of these different surveys. The minimum and maximum values, and the names of the surveys corresponding to the min and max values are also given for information. For milk products, meats and fishes, the gaps between min and max values are less than a factor of 2 . For cereals and vegetables, it is about 2; in the case of the category "Root vegetables and fruits", the gap of a factor of 3 is linked to a very high consumption of fruits from the Tricastin survey. All the previous studies do not provide enough detail of the consumption of seafood considering its high ${ }^{210} \mathrm{Po}$ activity and thus potentially high contribution to the dose. However, it appears that the total quantity of seafood consumed by people living close to the sea (Gravelines, Blayais and Nord-Cotentin surveys) is about 34 to $44 \mathrm{~kg} \cdot \mathrm{y}^{-1}$, whereas it is only 15 to $25 \mathrm{~kg} \cdot \mathrm{y}^{-1}$ as seen from the national surveys (INSEE, INCA1 and INCA2) and in sites located away from the sea (Marcoule, Chinon and Tricastin). These consumption rates are consistent with the value of $36.8 \mathrm{~kg} \cdot \mathrm{y}^{-1}$ given by the French Institute for Agricultural Food and Seafood (FranceAgrimer, 2012). The survey named CALIPSO focused specifically on seafood consumption among 1200 persons living in seaside sites (Le Havre, Lorient, La Rochelle and Toulon) and qualified as high seafood consumers. This survey is also interesting because it details the consumption rates for most fish, crustacean and shellfish species, allowing one to obtain separate consumed quantities for the three seafood categories of Table 1 (Table 3).

From CALIPSO and AGRIMER data we can assume that fishes represent around $70 \%$ of the total quantity of seafood consumed. The surveys around the Gravelines, Blayais and Nord-Cotentin sites and the conclusions of the CALIPSO project show that the quantities consumed by the biggest seafood consumers (percentiles 95) are around $150 \mathrm{~kg} \cdot \mathrm{y}^{-1}$ (from 135 to $161 \mathrm{~kg} \cdot \mathrm{y}^{-1}$ ), corresponding to a daily rate of 40 g.d $\mathrm{d}^{-1}$.

The last element considered in this study is the dose conversion factors published in ICRP Publication 119 (2012).

\section{Results}

Due to the variability of the consumption of shellfish and crustaceans, and their significance in terms of the internal dose, it seems more appropriate to distinguish 4 cases.

- The dose received by a large majority of the population who consume about $4.6 \mathrm{~kg} \cdot \mathrm{y}^{-1}$ of seafood is about $319 \mu \mathrm{Sv}^{-\mathrm{y}^{-1}}$. As expected, this dose is practically entirely due to ${ }^{210} \mathrm{Po},{ }^{210} \mathrm{~Pb},{ }^{228} \mathrm{Ra}$ and ${ }^{226} \mathrm{Ra}$.

- People who do not consume any shellfish or crustaceans would receive a dose of $193 \mu \mathrm{Sv}^{-1} \mathrm{y}^{-1}$. This dose is 1.5 times above the UNSCEAR assessment $\left(127 \mu \mathrm{Sv}^{-1} \mathrm{y}^{-1}\right.$ without water consumption) based on a smaller consumption of "fish products" (15 kg. $\left.\mathrm{y}^{-1}\right)$ without clearly considering shellfish and crustaceans.

- For the people who regularly consume shellfish and crustaceans the surveys carried out in seaside sites (from Table 2 and the mean values of Table 3 ) give similar results: around $730 \mu \mathrm{Sv}^{-1} \mathrm{y}^{-1}$.

- The range of doses received by the big consumers of seafood (about 135 to $161 \mathrm{~kg} \cdot \mathrm{y}^{-1}$ ) as characterized by the percentile 95 of the CALIPSO survey (adults and seniors) and Nord-Cotentin reaches 2,000 to $2,600 \mu \mathrm{Sv}_{\mathrm{y}} \mathrm{y}^{-1}$.

The dose assessments provided in the literature are sometimes partial and can concern only some kinds of foodstuffs and some radionuclides. Table 4 allows comparing all these evaluations by giving the foodstuffs or the nuclides considered, 
Table 2. Mean, min and max values of the quantity consumed for each foodstuff categories from the different surveys, and names of the surveys corresponding to the min and max values in $\mathrm{kg} \cdot \mathrm{y}^{-1}$.

\begin{tabular}{lccccc}
\hline Foodstuffs cat. & Mean & Min & Survey & Max & Survey \\
\hline Milk products & 118 & 102 & INCA2 & 155 & Nord-Cotentin \\
Meats & 85 & 71 & INCA2 & 98 & Blayais \\
Cereals & 82 & 66 & Marcoule & 123 & Nord-Cotentin \\
Leafy vegetables & 31 & 22 & INCA1 & 40 & Tricastin \\
Root veg. \& fruits & 214 & 128 & INCA1 & 337 & Tricastin \\
Fishes 1** & 15 & 6 & INSEE & 19 & Tricastin \\
Fishes 2** & 20 & 15 & Gravelines & 23 & Nord-Cotentin \\
Shellfish and crustaceans 1* & 4.6 & 2 & INCA2 & 6 & Tricastin \\
Shellfish and crustaceans 2** & 19 & 19 & Nord-Cotentin & 20 & Gravelines \\
\hline
\end{tabular}

${ }^{*}$ National value and continental sites: INCA1, INSEE, Marcoule, Tricastin and Chinon surveys.

${ }^{* *}$ for seaside sites: Gravelines, Blayais and Nord-Cotentin surveys.

and some comments in order to compare with the corresponding partial internal dose from our study. This table shows that the variability of doses is mainly linked to the consumption rates considered, and notably to seafood consumption rates (Table 4). This appears when comparing the results obtained by Pietrzack-Flis et al. (2001) with those of Kannan et al. (2001), or when comparing Pollard et al. (1998) with Rollo et al. (1992) in the case of the United Kingdom. Desideri et al. (2011) following Ryan et al. (1999) propose, as in this study, considering the populations with radically different behaviors regarding the consumption of seafood separately. One can note that among the highest dose assessments, Kannan et al. (2001) give a value of $3,364 \mu \mathrm{Sv} \cdot \mathrm{y}^{-1}$ linked to the consumption of $25 \mathrm{~kg} \cdot \mathrm{y}^{-1}$ of crabs.

Behind seafood, cereals exhibit the highest activities for the four main nuclides. Considering their lowest $\left(66 \mathrm{~kg} \cdot \mathrm{y}^{-1}\right)$ and highest consumption rates $\left(123 \mathrm{~kg} . \mathrm{y}^{-1}\right)$ observed from the various surveys and without any compensation by the consumption of other kinds of foodstuffs, the associated dose variability would be only $17 \%$. Even the absence of cereal consumption would reduce the average dose of $319 \mu \mathrm{Sv}_{\mathrm{y}} \mathrm{y}^{-1}$ by only $26 \%$.

Concerning water consumption, the 12,000 samples analyzed annually in France for the sanitary control of tap water put bounds on the highest corresponding doses but do not allow determining an average. Indeed, only the samples exceeding the French guideline values $(0.1 \mathrm{~Bq} / \mathrm{L}$ for alpha global activity and $1 \mathrm{~Bq} / \mathrm{L}$ for beta global activity) are subject to further analysis to assess doses.

It should also be noted that, unlike other foodstuffs for which the mean values have a meaning, a person consumes his tap water or the bottled water of his convenience. Thus, the individual dose is directly related to the dispensing unit or to consumer choices rather than to the national average. In addition, the activities of U-Th decay products in water and their relative contributions to the dose are completely erratic and cannot be predicted without specific measurement results. Although doses are often linked to radium or uranium activities, they can also result from isolated high activities of ${ }^{210} \mathrm{Po}$ or ${ }^{210} \mathrm{~Pb}$ due to physical and chemical characteristics of the water. In this context, we can only say that the dose received by French adults consuming 730 L.y ${ }^{-1}$ could exceed $100 \mu \mathrm{Sv}^{-1} \mathrm{y}^{-1}$ only for less than $0.2 \%$ of the tap water consumers
Table 3. Mean value and percentile- 95 of seafood consumption for adults and seniors from the CALIPSO survey in kg. $\mathrm{y}^{-1}$.

\begin{tabular}{lcccc}
\hline \multirow{2}{*}{ Foodstuff cat. } & \multicolumn{2}{c}{ Adults (17-64 y) } & \multicolumn{2}{c}{ Seniors $(>\mathbf{6 5}$ y) } \\
& Mean & P95 & Mean & P95 \\
\hline Large fishes/cephalop. & 31 & 69 & 36 & 71 \\
Small fishes & 4,2 & 19 & 6,5 & 30 \\
Crustaceans & 6.7 & 27 & 8.4 & 31 \\
Shellfish & 4.6 & 19 & 4.7 & 20 \\
Total & 46.5 & 161 & 55.5 & 152 \\
\hline
\end{tabular}

(ASN-DGS-IRSN, 2011) or for people who have chosen one of the $4 \%$ of bottled waters whose consumption can lead to exceeding this dose (ASN-DGS-IRSN, 2013). For the wide majority of French adults, the dose by ingestion of water is probably between a few $\mu \mathrm{Sv} \cdot \mathrm{y}^{-1}$ and a few tens of $\mu \mathrm{Sv} \cdot \mathrm{y}^{-1}$.

\section{Conclusion}

This study provides the first dose assessment to the French adult population due to the intake of radionuclides from the decay chains of uranium and thorium. This estimate was made possible by the acquisition during the last 15 years of data about the main radionuclide contributors to this dose: ${ }^{210} \mathrm{Po}$, ${ }^{210} \mathrm{~Pb},{ }^{228} \mathrm{Ra}$ and ${ }^{226} \mathrm{Ra}$. For most adults this dose was evaluated at $319 \mu \mathrm{Sv}_{\mathrm{y}} \mathrm{y}^{-1}$, being 1.5 times higher than the UNSCEAR assessment (without water consumption), which has been considered until now as the reference for France. The gap is mainly due to more precise estimates of seafood activities, notably for ${ }^{210} \mathrm{Po}$, and of their consumption. As shown in the literature, the variability of dietary habits concerning shellfish and crustaceans is the main cause of the variability for this dose. Some specific data show that people living near the French coasts consume more seafood, leading to a dose of around $730 \mu \mathrm{Sv}_{\mathrm{y}} \mathrm{y}^{-1}$. The literature studies based on similar consumptions of these products obtain similar results.

The range of doses received by the biggest consumers of seafood would reach 2,000 to $2,600 \mu \mathrm{Sv} . \mathrm{y}^{-1}$.

However, a population who does not consume shellfish or crustaceans at all probably exists, who would receive a dose lower than $200 \mu \mathrm{Sv}_{\mathrm{y}} \mathrm{y}^{-1}$. This variable behavior regarding seafood overshadows all the other cause of variability, notably 
Table 4. Comparison of different dose assessments.

\begin{tabular}{|c|c|c|c|c|c|}
\hline $\begin{array}{l}\text { Dose } \\
\left(\mu \mathrm{Sv}_{.} \mathrm{y}^{-1}\right)\end{array}$ & Nuclides & Foodstuffs & $\begin{array}{l}\text { Comments; rations } \\
\text { in kg. } \mathrm{y}^{-1}\end{array}$ & References & $\begin{array}{c}\text { This study } \\
\left(\mu \mathrm{Sv}_{.} \mathrm{y}^{-1}\right)\end{array}$ \\
\hline 90 & All & All & $\begin{array}{c}\text { Fish: } 1.9 \\
\text { No crustaceans, no shellfish }\end{array}$ & Pietrzack-Flis et al., 2001 & 319 \\
\hline 731 & ${ }^{210} \mathrm{Po}$ & All & Fish: 25; Crustaceans: 50 & Kannan et al., 2001 & 319 and $640^{*}$ \\
\hline 123 & ${ }^{210} \mathrm{Po}$ & Vegetable foodstuffs & Vegetarian diet & Kannan et al., 2001 & 98 \\
\hline 65 to 118 & ${ }^{210} \mathrm{Po}$ and ${ }^{210} \mathrm{~Pb}$ & Vegetable foodstuffs & & McDonald et al., 1999 & 98 \\
\hline 96 & ${ }^{210} \mathrm{Po}$ & Seafood & $\begin{array}{c}\text { Fish: } 14.5 \text {; Crustaceans: } 0.9 \\
\text { shellfish: } 0.9\end{array}$ & Desideri et al., 2011 & 160 \\
\hline 466 & ${ }^{210} \mathrm{Po}$ & Seafood & Fish: 73.5; Crustaceans: 3.6 & Desideri et al., 2011 & 561 \\
\hline 20 & ${ }^{210} \mathrm{Po}$ & Seafood & $\begin{array}{c}\text { Shellfish: } 3.6 \\
\text { Fish: } 8.5 \\
\text { Crustaceans and shells: } 0.5\end{array}$ & Pollard et al., 1998 & 165 \\
\hline 150 to 270 & All & Seafood & $\begin{array}{c}\text { Fish: } 20 \text { to } 37 \\
\text { Shellfish: } 4 \text { to } 6 \\
\text { Crustaceans: } 4 \text { to } 8\end{array}$ & Rollo et al., 1992 & 176 and $582^{*}$ \\
\hline 311 & ${ }^{210} \mathrm{Po}$ and ${ }^{210} \mathrm{~Pb}$ & Seafood & Based on tonnage caught & Yamamoto et al., 1994 & 173 and $575^{*}$ \\
\hline 216 & ${ }^{210} \mathrm{Po}$ and ${ }^{210} \mathrm{~Pb}$ & Seafood & & Yamamoto et al., 1994 & 173 and $575^{*}$ \\
\hline 46 to $129 * *$ & ${ }^{210} \mathrm{Po}$ & Seafood & $\begin{array}{l}\text { Fish: } 24 \text {; shellfish: } 10 ; \\
\text { no crustaceans }\end{array}$ & & 165 \\
\hline 240 & ${ }^{210} \mathrm{Po}$ & Fish & Fish: 25 & Louw et al., 2009 & 48 \\
\hline $1000-1700$ & ${ }^{210} \mathrm{Po}$ & Cereals & $\begin{array}{l}\text { Cereals: } 150 \\
\text { Activity from } 6 \text { to } 10 \mathrm{~Bq} \cdot \mathrm{kg}^{-1}\end{array}$ & Louw et al., 2009 & 40 \\
\hline
\end{tabular}

${ }^{*}$ considering rations of $20 \mathrm{~kg} \cdot \mathrm{y}^{-1}$ for fishes and $19 \mathrm{~kg} \cdot \mathrm{y}^{-1}$ of crustaceans and shellfish; mean values from the surveys on marine sites (Gravelines, Blayais and Nord-Cotentin).

${ }^{* *}$ A correction factor of 0.6 has been applied to take into account a fishing-consumption delay as proposed by UNSCEAR. To be compared with other doses, the corrected values would be 77 and $214 \mu \mathrm{Sv}_{\mathrm{y}} \mathrm{y}^{-1}$.

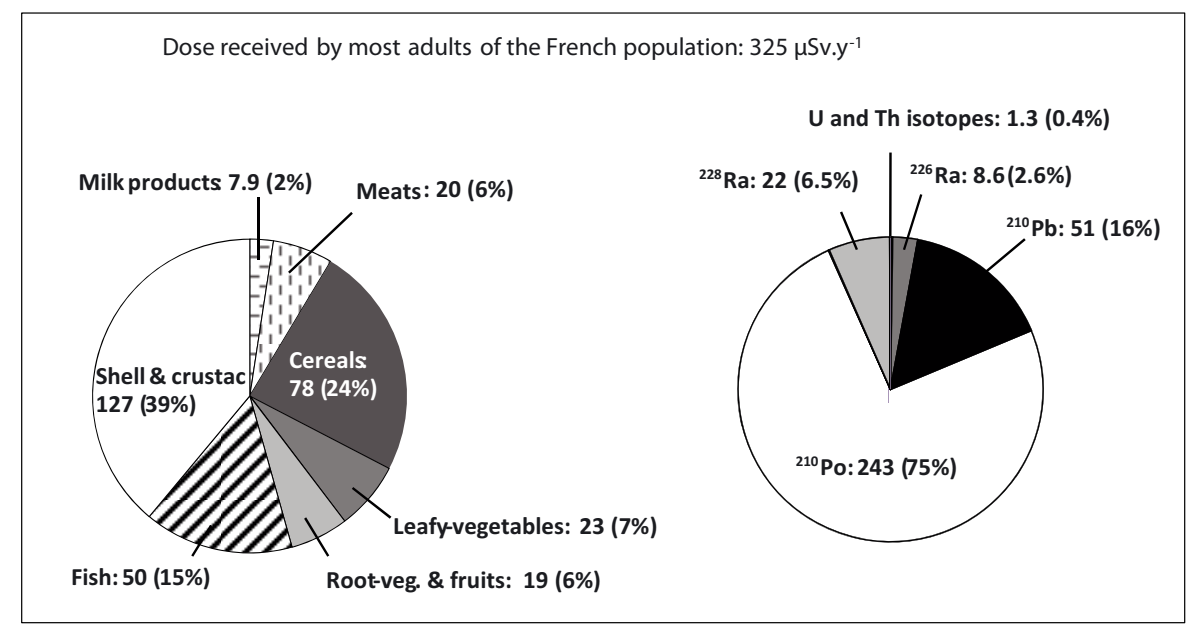

Fig. 1. Contributions of foodstuff categories and radionuclides to the dose received by most adults of the French population.

the slight gaps between the rations of other kinds of foodstuffs, even cereals, which exhibit the highest ${ }^{210} \mathrm{Po}$ activities behind seafood. Moreover, the studies carried out on polonium, lead and radium activities in French foodstuffs show that no distinctions can be made between sites regarding their content of uranium and thorium in soils.

\section{References}

ASN-DGS-IRSN (2011) Autorité de Sûreté Nucléaire, Direction Générale de la Santé et Institut de Radioprotection et de Sûreté
Nucléaire. La qualité radiologique de l'eau du robinet en France. Rapport ASN-DGS-IRSN 2011.

ASN-DGS-IRSN (2013) Autorité de Sûreté Nucléaire, Direction Générale de la Santé et Institut de Radioprotection et de Sûreté Nucléaire. La qualité radiologique des eaux conditionnées produites en France. Rapport ASN-DGS-IRSN Septembre 2013.

Bertrand M. (1993) Consommation et lieux d'achat des produits alimentaires. Rapport INSEE ISBN 2-11-066133-X.

Blanco Rodriguez P., Vera Tome F., Lozano J.C. (2002) About the assumption of linearity in soil-to-plant transfer factors for uranium and thorium isotopes and ${ }^{226} \mathrm{Ra}$, Sci. Tot. Environ. 284, 167-175. 
Desideri D., Meli M.A., Roselli C. (2011) Natural radionuclides in seafood from the central Adriatic sea (Italy), Health Phys. 100 (2), 160-166.

Dufour A., Volatier J.L. (1998) Enquête sur la consommation alimentaire dans le Nord-Cotentin pour la COGEMA. CREDOC.

FranceAgrimer (2012) Consommation des produits de la pêche et de l'aquaculture ; données statistiques 2011.

ICRP Publication 119 (2012) Compendium of Dose Coefficients based on ICRP Publication 60. Ann. ICRP 41 (Suppl.).

Kannan V., Iyengar M.A.R., Ramesh R. (2001) Dose estimates to the public from ${ }^{210}$ Po ingestion via dietary sources at Kalpakkam (India), Appl. Radiat. Isotopes 54, 663-674.

Lafay L. (2009) Étude Individuelle Nationale des Consommations Alimentaires 2 (INCA 2) (2006-2007). Rapport AFSSA.

Louw I., Faanhof A., Kotze D. (2009) Determination of polonium-210 in various foodstuffs after microwave digestion, Radioprotection 44 (5), 89-95.

McDonald P., Jackson D., Leonard D.R.P., McKay K. (1999) An assessment of ${ }^{210} \mathrm{~Pb}$ and ${ }^{210} \mathrm{Po}$ in terrestrial foodstuffs from regions of England and Wales, J. Environ. Radioact. 43 (1), 15-29.

Mourlon C. (2012) Choix des valeurs de paramètres des modules anthropiques et alimentaires dans SYMBIOSE. Rapport IRSN/SERIS 2012-19.

Parache V. (2009) Projet SENSIB - Enquête alimentaire autour du site nucléaire de Chinon-Avoine : résultats et comparaison avec des enquêtes précédentes. Rapport IRSN/DEI/SESURE 2009-24.

Parache V. (2010) Projet SENSIB - Résultats de l'enquête alimentaire autour du site de Pierrelatte-Tricastin (2004-2005). Rapport IRSN/DEI/SESURE No. 2010-31.

Parache V. (2011) Projet SENSIB - Enquête alimentaire autour du site nucléaire de Marcoule (2010) : Méthode et Résultats. Rapport IRSN/DEI/SESURE No. 2011-07.

Parache V. (2012) Projet SENSIB - Enquête alimentaire autour du site nucléaire de Gravelines (2011) : Méthode et Résultats. Rapport IRSN/DEI/SESURE No. 2012-09.

Picat P., Calmet D., Louvat D., Vray F., Lemaitre N., Linden G., Barbey P., Pigree G., Bourcier T., Levy F., Le Bar S., Baron Y., Delacroix D., Panaïva E., De Bruyne T., Hervé J.Y., Beguinel P., Cabanne N., De Paepe A., Santucci C., Prot T., Matrat J.L.,
Tillie J.L. (2002) Radioactivité d'origine naturelle dans l'environnement en France : niveaux non perturbés par l'homme, Radioprotection 37 (3), 283-327.

Pietrzack-Flis Z., Suplinska M.M., Rosiak L. (1997a) The dietary intake of ${ }^{238} \mathrm{U},{ }^{234} \mathrm{U},{ }^{230} \mathrm{Th},{ }^{232} \mathrm{Th},{ }^{228} \mathrm{Th}$ and ${ }^{226} \mathrm{Ra}$ from food and drinking water by inhabitants of the Walbrzyck region, $J$. Radioanal. Nucl. Chem. 222 (1-2), 189-193.

Pietrzack-Flis Z., Chrzanowski E., Dembinska S. (1997b) Intake of ${ }^{226} \mathrm{Ra},{ }^{210} \mathrm{~Pb}$ and ${ }^{210} \mathrm{Po}$ with food in Poland, Sci. Tot. Environ. 203 (2), 157-165.

Pietrzack-Flis Z. Rosiak L., Suplinska M.M., Chrzanowski E., Dembiska S. (2001) Daily intakes of ${ }^{238} \mathrm{U},{ }^{234} \mathrm{U},{ }^{232} \mathrm{Th},{ }^{230} \mathrm{Th}$, ${ }^{228} \mathrm{Th}$ and ${ }^{226} \mathrm{Ra}$ in the adult population of central Poland, Sci. Tot. Environ. 273, 163-169.

Pollard D., Ryan T.P., Dowdall A. (1998) The dose to Irish seafood consumers from ${ }^{210}$ Po, Radiat. Prot. Dosim. 75 (1-4), 128-142.

Renaud Ph., Roussel-Debet S., Pourcelot L., Gurriaran R. (2015a) ${ }^{226} \mathrm{Ra}$ and ${ }^{228} \mathrm{Ra}$ in French foodstuffs, Radioprotection 50 (2), 111-115.

Renaud Ph., Roussel-Debet S., Pourcelot L., Thébault H., Loyen J., Gurriaran R. (2015b) ${ }^{210} \mathrm{~Pb}$ and ${ }^{210} \mathrm{Po}$ in French foodstuffs, Radioprotection $\mathbf{5 0}$ (2), 123-128.

Rollo S.F.N., Camplin W.C. Allignton D.J., Young A.K. (1992) Natural radionuclides in the UK marine Environment, Radiat. Prot. Dosim. 45 (1-4), 203-209.

Ryan T.P., Dowdall A.M., McGarry A.T., Pollard D., Cunningham J.D. (1999) ${ }^{210}$ Po in Mytilus edulis in the Irish marine environment, J. Environ. Radioact. 43, 325-342.

UNSCEAR (2000) United Nations Scientific Committee on the Effects of Atomic Radiation. Source and effects of ionizing radiation. Report of the General Assembly, Vol. 1 with scientific annexes.

Volatier J.L. (2000) Enquête INCA (Individuelle et Nationale sur les Consommations Alimentaires). CREDOC, AFSSA, Ministère de l'Agriculture et de la Pêche. Éditions Tec et Doc, Paris.

Yamamoto M., Abe T., Kuwabara J., Komura K., Ueno K., Takizawa Y. (1994) Polonium-210 and lead-210 in marine organisms: intake levels for Japanese, J. Radioanal. Nucl. Chem. 178 (1), 81-90.

Cite this article as: $\mathrm{Ph}$. Renaud, V. Parache, S. Roussel-Debet. Internal doses of French adult population linked to the intake of radionuclides from the decay-chains of uranium and thorium by foodstuffs ingestion. Radioprotection 50(2), 117-121 (2015). 